\title{
REVIEW \\ Ecology and Control of Eriophyid Mites Injurious to Fruit Trees in Japan
}

\author{
Wataru ASHIHARA ${ }^{1 *}$, Akira KONDO ${ }^{2}$, Manabu SHIBAO ${ }^{3}$, \\ Hiroshi TANAKA ${ }^{3}$, Katsumi HIEHATA ${ }^{4}$ and Katsunori IZUMI ${ }^{5}$ \\ 1 Department of Plant Protection, National Institute of Fruit Tree Science, National Agriculture and \\ Bio-oriented Research Organization (Tsukuba, Ibaraki 305-8605, Japan) \\ 2 Agricultural Experiment Station, Okayama Prefectural General Agriculture Center \\ (Sanyo-cho, Okayama 709-0801, Japan) \\ 3 Agricultural, Food and Environmental Sciences Research Center of Osaka Prefecture \\ (Habikino, Osaka 583-0862, Japan) \\ 4,5 Yamaguchi Prefectural Hagi Citrus Experiment Station (Hagi, Yamaguchi 758-0011, Japan)
}

\begin{abstract}
Studies on the damage, biology, natural enemies and management of the economically important eriophyid mites: persimmon bud mite, Aceria diospyri, ficus mottle mite, Aceria ficus, peach silver mite, Aculus fockeui, and pink citrus mite, Aculops pelekassi in Japan are reviewed. A. diospyri and A. pelekassi mainly cause damage to the fruits of host plants. The rust symptom on persimmon fruits by $A$. diospyri differs among varieties. A. ficus causes economic loss in fig with leaf mosaic, leaf malformation, fruit mosaic, and fruit drop. A. fockeui injures peach leaves, reduces the sugar content of the fruit, and the damaged trees have lower vigor due to post-harvest defoliation. These mites overwinter in buds of host plants as adults. Overwintered mites begin to reproduce on the leaves after late May or mid-April. Fruit infesting mites, A. diospyri and A. pelekassi, migrate to and infest fruits after June. Since the density of overwintered A. ficus is high in large dormant fig buds, cutting of the big buds is effective to reduce mite damage in the next season. Several acaricides, insecticides and fungicides are effective against the eriophyid mites. A. pelekassi populations with dithiocarbamate-fungicide resistance were confirmed in the early 1990's and outbreaks of the mite sometimes cause severe damage to citrus fruits. It was found that some phytoseiids, a tydeid and a stigmaeid feed on these eriophyids. Phytoseiidae mites play an important role in the control of $A$. diospyri, A. ficus and A. fockeui populations in low densities. A marked resurgence in A. fockeui populations occurs after synthetic pyrethroids are sprayed, because they have no effect on A. fockeui but are harmful to the predators, such as phytoseiid mites.
\end{abstract}

Discipline: Insect pest

Additional key words: Aceria diospyri, Aceria ficus, Aculus fockeui, Aculops pelekassi, Phytoseiidae, citrus, peach, fig, seasonal cycle, damage

\section{Introduction}

Eriophyid mites are the smallest phytophagous mites ranging in length from 0.15 to $0.3 \mathrm{~mm}$. Most of them are host specific, and cause gall formation, russeting, and leaf or shoot defoliation of host plants. Until now 15 species of eriophyids have been found on fruit trees in Japan ${ }^{8,9}$. Persimmon bud mite, Aceria diospyri Keifer, ficus mottle mite, Aceria ficus (Cotte), peach silver mite, Aculus fockeui (Nalepa et Trouessart), Japanese pear rust mite, Eriophyes chibaensis Kadono, pink citrus mite, Aculops pelekassi (Keifer) and grape bud mite, Colomerus vitis (Nalepa) are known as agriculturally important species. The small size of these mites make them difficult to detect. Only limited biological informa-

\footnotetext{
Present address:

${ }^{4}$ Yamaguchi Prefectural Oshima Citrus Experiment Station (Oshima, Yamaguchi 742-2805, Japan)

${ }^{5}$ Yamaguchi Agricultural Experiment Station (Ouchi, Yamaguchi 753-0214, Japan)

*Corresponding author: fax +81-29-838-6541; e-mail jbc2459@affrc.go.jp

Received 8 September 2003; accepted 18 December 2003.
} 
tion is currently available except for $E$. chibaensis ${ }^{8}$ and $A$. pelekassi $i^{26}$.

Studies on the biology and integrated pest management of A. diospyri, A. ficus and A. fockeui were conducted. These mites were reported relatively recently in Japan and have become important in their respective host plant orchards. A. pelekassi had been considered to be an important secondary citrus pest, because the mite population had been controlled not only by acaricides but by fungicide application. At present, its pest status has increased due to the establishment of populations resistant to some fungicides. In this paper, the present status of these pests and recent studies on the bionomics, chemical control and biological control of the 4 eriophyids are reviewed.

\section{Persimmon bud mite, Aceria diospyri}

Persimmon bud mite, Aceria diospyri is known in USA, Brazil and New Zealand to cause blackening of persimmon (Diospiros kaki Thunb.) fruits and fruit drop $^{11,18,25}$. In Japan, $A$. diospyri was first recorded in 1981 by Nemoto (1982) ${ }^{22}$. Since rust injury caused by $A$. diospyri on fruits of cultivar "Saijyo" was found in 1992, the mite has been an economically important pest of this cultivar in Yamaguchi Prefecture ${ }^{1,3}$.

Table 1. Percent of rust injured fruits by Aceria diospyri on some persimmon cultivars

\begin{tabular}{cccccc}
\hline \hline Year & "Saijyo" & $\begin{array}{c}\text { "Hiratane- } \\
\text { nashi" }\end{array}$ & $\begin{array}{c}\text { "Tone- } \\
\text { wase" }\end{array}$ & "Jiro" & "Fuyu" \\
\hline 1992 & - & 0.0 & 0.0 & 36.0 & 0.9 \\
1993 & 87.5 & 0.0 & - & 33.8 & 0.0 \\
\hline
\end{tabular}

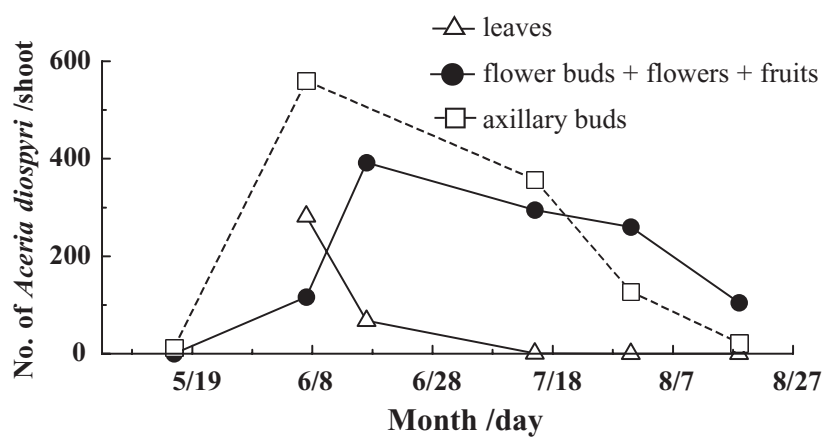

Fig. 2. Transition of Aceria diospyri population on leaves, flower buds + flowers + fruits and axillary buds of the shoot on cultivar "Saijyo" in Hagi, 1997

\section{Damage}

Rust damage caused by $A$. diospyri initially appears, in mid-July, as black marks from the calyx. The damaged fruit surface cracks due to fruit enlargement and a darkbrown rust symptom appears during the late enlargement stage to the harvest stage (Fig. 1-A). The rust damage on "Saijyo" and "Jiro", which have side furrows, is particularly extreme. Very few of these symptoms are seen on "Fuyu", and none at all on "Hiratanenashi" and "Tonewase", which have no furrows (Table 1). A. diospyri are concentrated in the furrow under the calyces on "Saijyo" and "Jiro". In some cases, black, petal-shaped damage appears around the calyx in "Fuyu" (Fig. 1-B). The results of mite control experiments suggested that this injury is also caused by $A$. diospyri infestation ${ }^{1}$.

\section{Seasonal cycle}

A. diospyri begins to reproduce in the dormant buds around mid-March. The first mite infestation on the leaves is found in dense trichomes by the midrib on the lower surface of the leaves, and moves towards the upper leaves of the foliation. In early to mid-June, the number of $A$. diospyri on the leaves suddenly decreases and the mites begin to migrate into the calyces when the leaves become hard and the flower petals drop. Most of $A$. diospyri inhabit the trichomes inside of the calyces. Some of them infest the surface of the fruits and cause

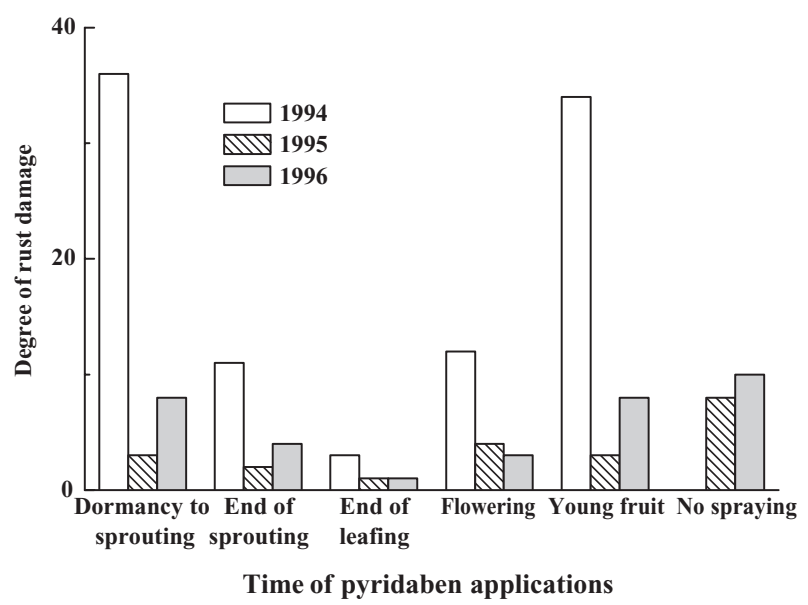

Fig. 3. Degree of rust damage by Aceria diospyri according to the time of pyridaben WP $(\times 1,000)$ application Fruits were separated into 3 categories of damage $(100,50$ and 17 degrees) and the mean degrees of damage were calculated. Machine oil EC $(\times 20)$ was sprayed on all test trees in the period of dormancy to sprouting. 

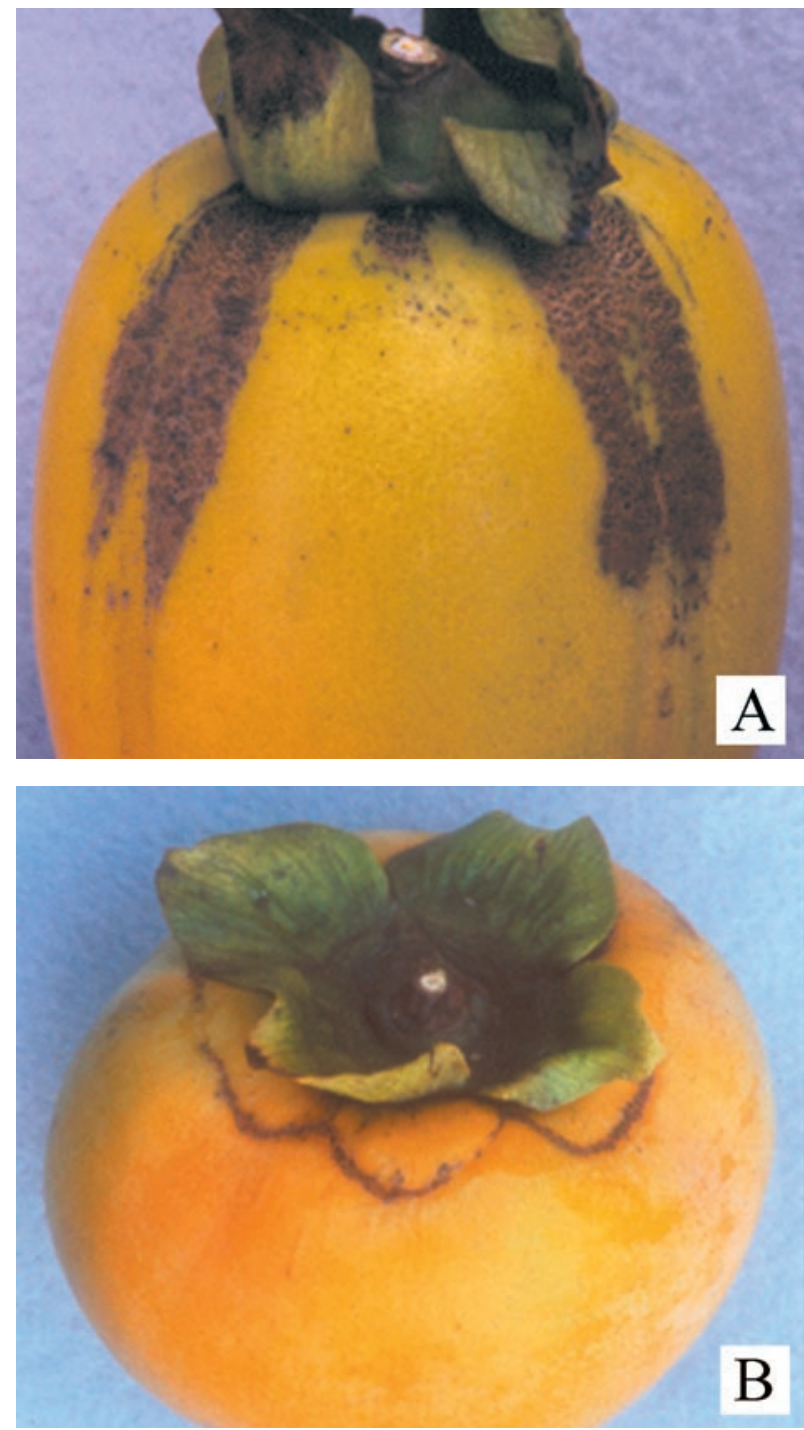

Fig. 1. Injury to persimmon fruits by Aceria diospyri A: "Saijyo", B: "Fuyu".

damage. The highest density of mites on fruits is found between mid-July and early August and the density decreases later. The leaf infestation is observed again on the secondary-growth-shoots in July and August. Invasion of $A$. diospyri individuals into newly formed axillary buds starts from mid-May (Fig. 2). The mites in the buds may hibernate without reproduction in the axillary buds because the number of eggs is extremely low ${ }^{3}$.

\section{Chemical control}

The experimental results on timing of chemical control showed that the optimum time for control was at the end of the leafing period between early May and midMay, when most of the mites inhabit expanded leaves (Fig. 3) ${ }^{3}$. The timely control of mites was also effective for preventing rust damage in the following year. A labo-
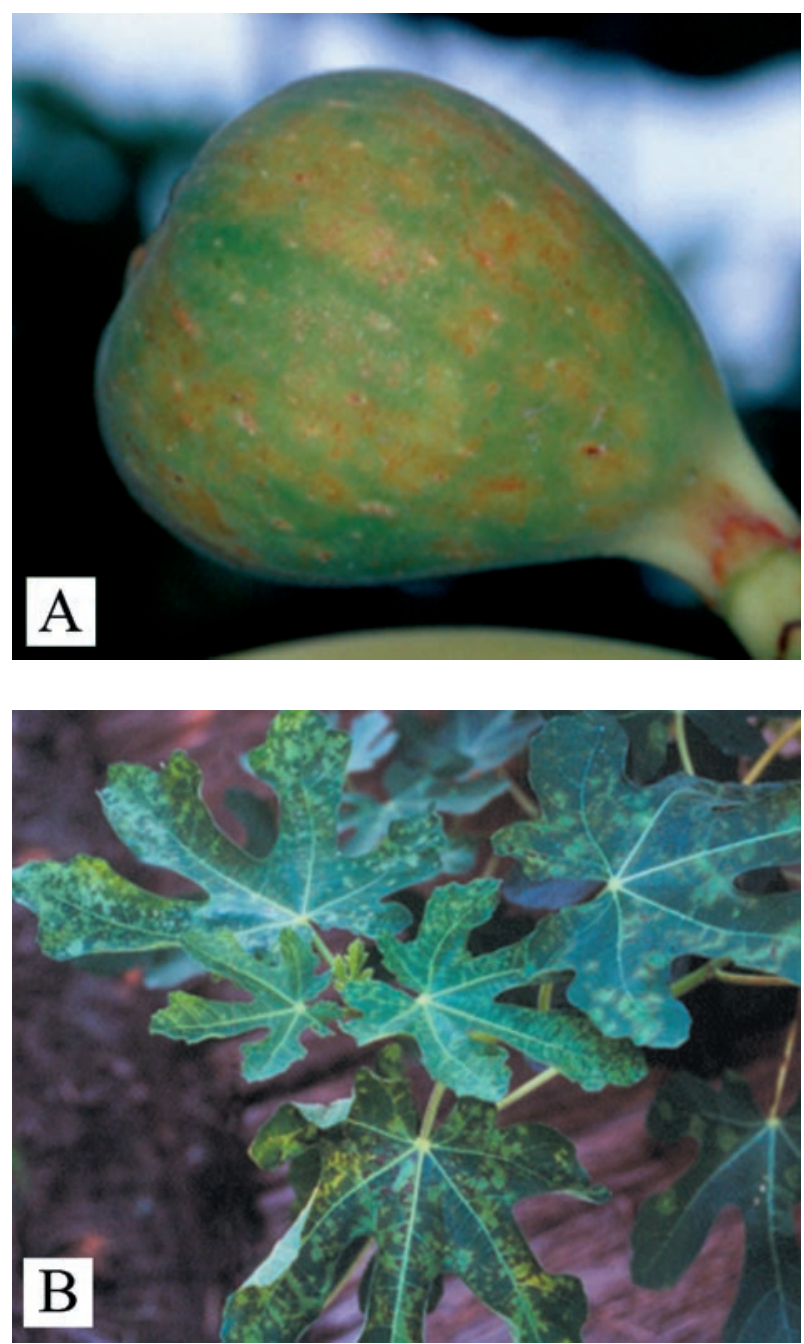

Fig. 4. Mosaic injury to fig by Aceria ficus A: fruit, B: leaf.

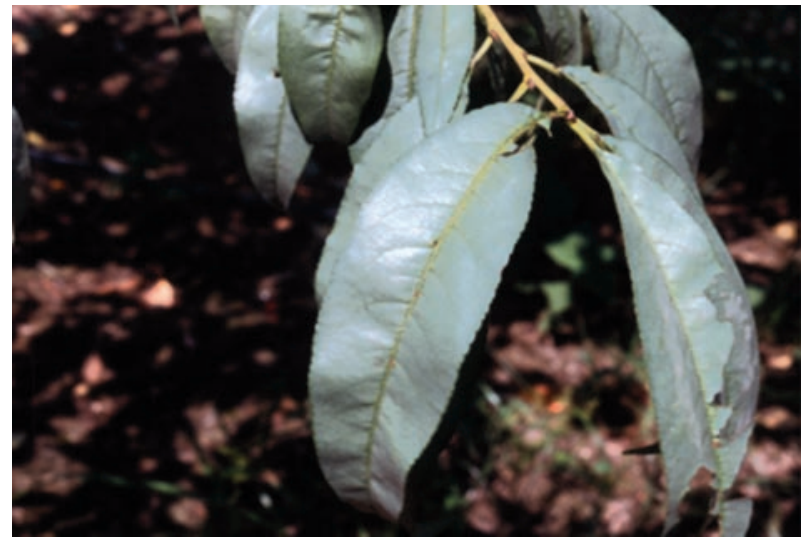

Fig. 8. Injury to peach leaves by Aculus fockeui

ratory bioassay showed that many pesticides and fungicides used for persimmon pests were effective for controlling bud mites, especially pyridaben, 
Table 2. Effects of pesticides on Aceria diospyri

\begin{tabular}{lc}
\hline \hline Pesticide, formulation (dilution) & $\begin{array}{c}\% \text { of } \\
\text { corrected } \\
\text { mortality }\end{array}$ \\
\hline Insecticides/ acaricides & 91 \\
Acephate, WP $(\times 1,000)$ & 100 \\
Pyridaphenthion, WP $(\times 1,000)$ & 98 \\
Permethrin, EC $(\times 2,000)$ & 96 \\
Methidathion, EC $(\times 1,000)$ & 93 \\
Buprofezin, WP $(\times 1,000)$ & 100 \\
Pyridaben, FL $(\times 2,000)$ & 90 \\
Dithiocarb, FL $(\times 1,000)$ & 94 \\
Chrolfenapyr, FL $(\times 2,000)$ & \\
Fungicides & 100 \\
Sulfer, WP $(\times 500)$ & 99 \\
Mancozeb, WP $(\times 400)$ & 87 \\
Ziram-thiram mixture, WP $(\times 600)$ & 95 \\
Propineb, WP $(\times 500)$ & 88 \\
Fluazinam, SC $(\times 2,000)$ & 97 \\
Dithianon, FL $(\times 600)$ & 98 \\
\hline
\end{tabular}

EC: emulsion concentrate, FL: flowable,

SC: soluble concentrate, WP: wettable powder.

pyridaphenthion, mancozeb and sulfer (Table 2). Only few cases of rust damage due to $A$. diospyri occur in fields where appropriate control against persimmon pests has been practiced. It can be thought of as a coincidental effect of using control agents targeting other pests and diseases $^{2,3}$.

\section{Biological control}

Several species of Phytoseiidae such as Phytoseius nipponicus Ehara, P. kishii Ehara, Typhlodromus vulgaris Ehara and Amblyseius eharai Amitai et Swirski are found on persimmon leaves, however, the densities of these phytoseiids are commonly low. Observations that $A$. diospyri population densities were low on fruits where phytoseiids were present may indicate the predators are effective for control of $A$. diospyri populations ${ }^{2}$.

Artificial leaf-to-fruit ratios of 5, 10, and 20 were made by removing available flowers and buds. In these tests phytoseiid population densities were high on the shoots of higher leaf-to-fruit ratios (Table 3 ). The results of the disbudding experiments showed that the level of rust damage was low on the shoots where the number of leaves per fruit were 10 and 20, compared to those where the number of leaves per fruit was 5; these had almost no buds removed. The lower rust damage on higher leaf-tofruit ratio shoots may be caused by concentration of phytoseiids on the fruits ${ }^{2}$.
Table 3. Relation between extent of disbudding and number of phytoseiids on young persimmon fruits

\begin{tabular}{cccc}
\hline \hline $\begin{array}{c}\text { Tree no. No. of leaves } \\
\text { per fruit }\end{array}$ & $\begin{array}{c}\% \text { of phytoseiids } \\
\text { on fruits }(\%)\end{array}$ & $\begin{array}{c}\text { No. of phytoseiids } \\
\text { per fruit }\end{array}$ \\
\hline 1 & 5 & 34.1 & 0.41 \\
& 10 & 44.4 & 0.67 \\
& 20 & 55.2 & 0.83 \\
\hline 2 & 5 & 11.6 & 0.14 \\
& 10 & 20.7 & 0.31 \\
\hline
\end{tabular}

Flower buds and flowers removed on May 29, 2000.

Examination conducted on June 19, 2000.

\section{Concluding remarks}

A. diospyri may be controlled easily by using highly effective pesticides and fungicides applied at an appropriate time. It is also possible to reduce damage caused by A. diospyri through the control of other major pests and diseases because certain agents may have an incidental effect of eliminating $A$. diospyri. As a cultural practice, disbudding to create a leaf-to-fruit ratio of about 15 is recommended in order to produce high quality fruits. This process is related to predation of $A$. diospyri by Phytoseiidae which leads to a reduction in rust damage by $A$. diospyri. Use of pesticides and fungicides with a lower impact on Phytoseiidae may potentially enhance the effect of Phytoseiidae.

(Hiehata \& Izumi)

\section{Ficus mottle mite, Aceria ficus}

The ficus mottle mite, Aceria ficus, is a worldwide pest of fig. In Japan, A. ficus was first recorded in 1979 in Tokyo and Saitama Prefectures ${ }^{21}$. In Osaka Prefecture with 53 ha of fig production, A. ficus first occurred in 1989 and has caused economic loss with leaf mosaic, leaf malformation, fruit mosaic, and fruit drop (Fig. 4) ${ }^{20,33}$.

\section{Seasonal cycle}

A. ficus occurred first in late May in low density. The density increased rapidly from mid-July and had a peak of 512 per shoot tip in mid-August. The density once decreased in September and increased again in October (Fig. 5) ${ }^{31}$. A. ficus prefers the bud in May, the second to last leaf in July and August, and the last leaf in October $^{27}$. A. ficus is rarely found on lower leaves of fig shoots. A. ficus adults overwinter in dormant fig buds from January to March. The density of overwintered adults is higher in big dormant buds (more than $6 \mathrm{~mm}$ in width and length) than in small ones (Table 4$)^{29}$.

\section{Cultural control}




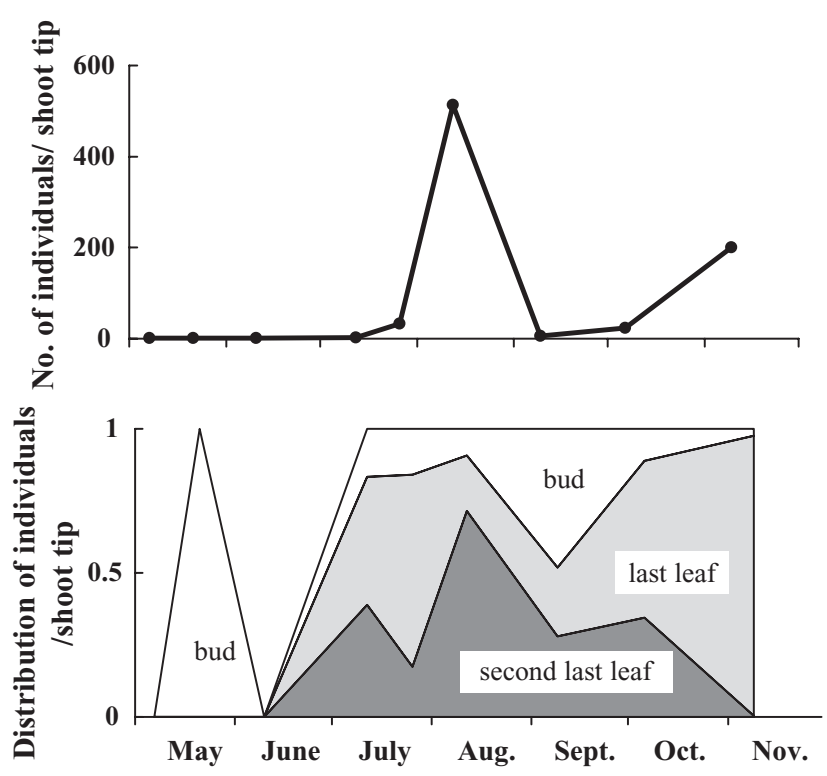

Fig. 5. Seasonal fluctuation in the number and distribution of Aceria ficus on fig shoot tip in 1993
To reduce the $A$. ficus overwintered population, 12.1 and 24.6 dormant buds per fig tree were cut off in March 1997 and 1998, respectively. In late June, the proportion of damaged shoots was $12.6 \%$ (cut plot) or $16.1 \%$ (control) in 1997 and $50.0 \%$ (cut plot) or $71.2 \%$ (control) in 1998. This suggests that cutting of the big dormant fig buds was effective in reducing the damage caused by $A$. ficus $^{31}$.

\section{Chemical control}

We examined the effect of 11 pesticides registered for fig against $A$. ficus by the leaf-disk method in 1994. Acaricides were effective except for hexythiazox and pyrethroid insecticides which were not effective (Table $5)^{28}$. Two fungicides, oxadixyl copper oxychlorid and thiophanate-methyl, were effective but with slow action, while the other two fungicides were not effective. When tebufenpyrad WP was sprayed on 10 June, 10 July and 8 August, 1996 in an open fig field, spraying once in July

Table 4. Number of overwintered Aceria ficus per dormant bud on fig in January-March 1994

\begin{tabular}{|c|c|c|c|c|}
\hline \multirow[b]{2}{*}{$\operatorname{Size}(\mathrm{mm})$} & \multicolumn{2}{|c|}{ Bud width } & \multicolumn{2}{|c|}{ Bud length } \\
\hline & $\begin{array}{l}\text { No. of individuals } \\
\text { /dormant bud }\end{array}$ & No. of buds & $\begin{array}{l}\text { No. of individuals } \\
\text { /dormant bud }\end{array}$ & No. of buds \\
\hline 1 & - & 0 & 0.5 & 30 \\
\hline 2 & 2.1 & 17 & 0.9 & 78 \\
\hline 3 & 2.3 & 54 & 1.9 & 75 \\
\hline 4 & 2.5 & 142 & 4.4 & 49 \\
\hline 5 & 2.4 & 55 & 2.8 & 23 \\
\hline$\geqq 6$ & 16.6 & 32 & 14.8 & 45 \\
\hline
\end{tabular}

Table 5. Effects of pesticides on Aceria ficus

\begin{tabular}{lcc}
\hline \hline Pesticide, formulation (dilution) & \multicolumn{2}{c}{$\%$ of corrected mortality } \\
\cline { 2 - 3 } & 2 days after spraying & 6 days after spraying \\
\hline Acaricides & 100 & 100 \\
Dicofol, EC $(\times 1,000)$ & 99.1 & 100 \\
Fenpyroximate, FL $(\times 2,000)$ & 100 & 100 \\
Pyridaben, FL $(\times 2,000)$ & 100 & 100 \\
Tebufenpyrad, EW $(\times 2,000)$ & 27.5 & 5.8 \\
Hexythiazox, WP $(\times 2,000)$ & & 1.7 \\
Insecticides & 47.9 & 27.5 \\
Permethrin, EC $(\times 2,000)$ & 39.9 & 100 \\
Tralomethrin, FL $(\times 2,000)$ & & 100 \\
Fungicides & 58.3 & 3.7 \\
Oxadixyl copper oxychlorid, WP $(\times 500)$ & 85.2 & 2.7 \\
Thiophanate-methyl, WP $(\times 1,000)$ & 14.6 & 9.6 \\
Copper sulfate, WP $(\times 1,000)$ & & \\
Copper hydroxide, WP $(\times 1,000)$ & & \\
\hline
\end{tabular}

EC: emulsion concentrate, EW: concentrated emulsion in water, FL: flowable, WP: wettable powder. 


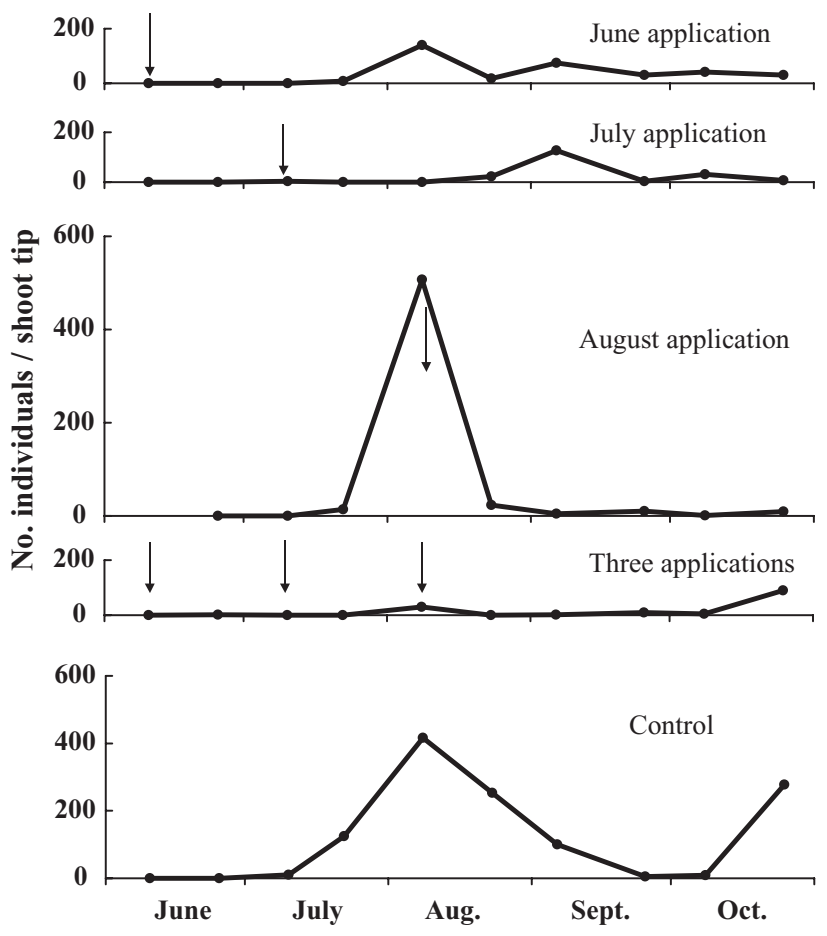

Fig. 6. Effect of application time of tebufenpyrad WP on the density of Aceria ficus in 1996

Arrows: application of tebufenpyrad WP.

was more effective than in June or August and equally effective when compared with spraying three times (Fig. $6)^{30}$. Thus, we can control $A$. ficus damage effectively by spraying once in early to mid-July.

\section{Biological control}

We identified 3 phytoseiid mites, Amblyseius californicus (McGregor), A. womersleyi Schicha and Phytoseius nipponicus Ehara, and one Tydeid mite, Pronematus sp., as natural enemies against $A$. ficus.

Table 6. Effects of pesticides on Amblyseius californicus

\begin{tabular}{lc}
\hline \hline Pesticide, formulation (dilution) & $\begin{array}{c}\% \text { of corrected mortality } \\
\text { 2 days after spraying }\end{array}$ \\
\hline Acaricides & 100 \\
Pyridaben, WP $(\times 2,000)$ & 100 \\
Tebufenpyrad, WP $(\times 2,000)$ & 100 \\
Fenpyroximate, FL $(\times 1,000)$ & 100 \\
Dicofol, EC $(\times 1,000)$ & 78.7 \\
Insecticides & 71.5 \\
$\quad$ Permethrin, EC $(\times 2,000)$ & \\
Tralomethrin, FL $(\times 2,000)$ & 9.3 \\
Fungicide & \\
Thiophanate-methyl, WP $(\times 1,000)$ &
\end{tabular}

EC: emulsion concentrate, FL: flowable, WP: wettable powder.
1997
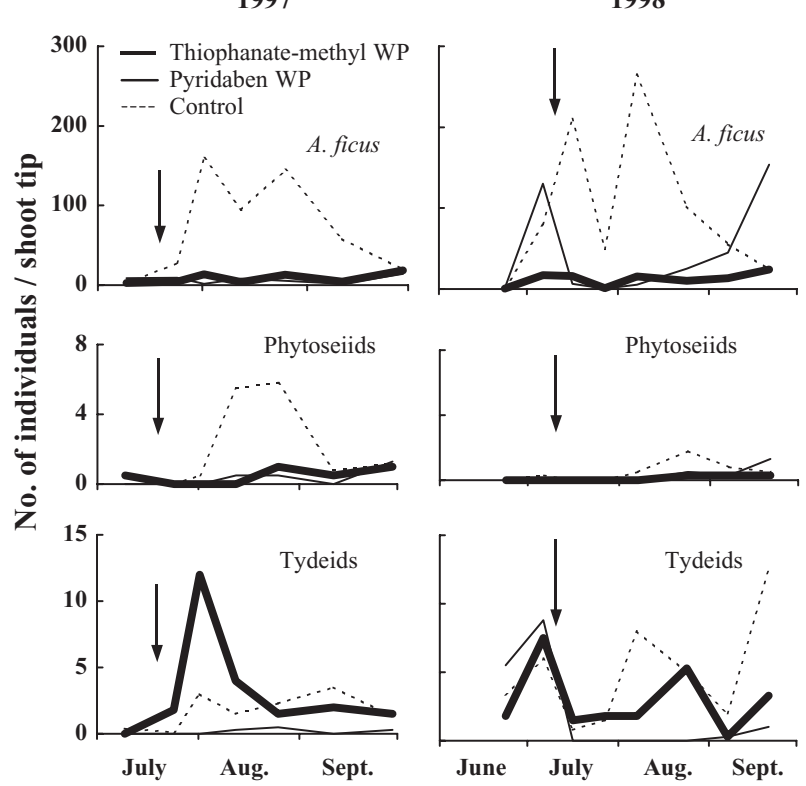

Phytoseiids
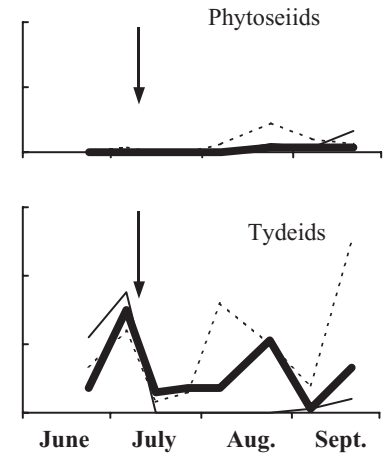

Fig. 7. Effect of application of acaricide or fungicide on the density of Aceria ficus and natural enemies Arrows: application of acaricide or fungicide.

We examined the toxicity of 7 pesticides against $A$. californicus by the leaf-disk method in 1998. All tested acaricides and pyrethroid insecticides were harmful, while a fungicide thiophanate-methyl was safe (Table $6)^{31}$. This suggests both $A$. californicus susceptibility and A. ficus resistance to pyrethroids cause $A$. ficus resurgence often observed in the field.

We sprayed thiophanate-methyl and examined the occurrence of $A$. ficus and natural enemies in an open fig field in 1997 and 1998. With thiophanate-methyl spraying, A. ficus density was similar to or lower than with pyridaben spraying, and Tydeid mite density was similar to the control (Fig. 7). We found thiophanate-methyl was useful for controlling A. ficus damage in the field ${ }^{31}$.

\section{IPM of $A$. ficus}

We propose an IPM (Integrated pest management) system for A. ficus as follows: (1) Big dormant fig buds should be cut in January-March to reduce overwintered A. ficus populations. (2) Pyrethroid spraying should be reduced to discourage A. ficus resurgence. (3) Acaricides should be applied in early to mid-July, the optimum timing for controlling A. ficus damage. (4) Thiophanatemethyl is useful to reduce $A$. ficus damage because it both kills $A$. ficus and preserves natural enemies.

(Shibao \& Tanaka) 


\section{Peach silver mite, Aculus fockeui}

The peach silver mite, Aculus fockeui, is a universal pest of peach, nectarine and almond ${ }^{6,11}$. In Japan, the mite was found on peach trees, Prunus persica Batch. in Yamanashi Prefecture in $1981^{35}$. Thereafter, infestations have been spreading gradually in Japan, and silvering on the upper leaf surface caused by the mite (Fig. 8) became conspicuous in most peach producing districts in the late 1980 's ${ }^{17}$.

\section{Damage}

Photosynthetic rates are significantly lower in injured leaves than in healthy leaves. Although no significant relationships between leaf injury levels at fruit harvest (late August) and fruit weights or fruit acidities were detected, the sugar content of fruit is negatively correlated with injury levels. The percentages of defoliation in late September and leaf injury levels at fruit harvest show a significant positive correlation. Enlargement of the floral bud volume is suppressed in severely damaged trees with $70-80 \%$ defoliation in late September compared to undamaged trees with $5-10 \%$ defoliation. Further, weight, sugar content and acidity of next year's fruit in severely damaged trees are all significantly lower than in undamaged ones. Thus, severe peach leaf injuries caused by A. fockeui reduce the sugar content of fruit in the current year and damaged trees have lower vigor due to postharvest defoliation, resulting in lower fruit quality in the next year ${ }^{13}$.

\section{Seasonal cycle}

Adults of A. fockeui overwinter in buds of peach trees in clusters and disperse to leaves at the time of foliation in mid-April, where the populations begin to increase thereafter. The population densities of $A$. fock- eui become high from June and show peaks in late July to early August, and become low in late September. $A$. fockeui densities are far lower on fruits with no injuries compared to those on the leaves. Most individuals inhabit the under leaf surfaces until June but also begin inhabiting the upper leaf surfaces from July, and disperse to overwintering sites at the time of defoliation. A. fockeui adults are captured on sticky traps at a distance of 20 $\mathrm{m}$ from a peach orchard, suggesting that they are highly dispersed by wind besides walking ${ }^{16}$.

As shown in Table 7, A. fockeui appears to be a species adapted to relatively high temperatures. The duration from egg to adult at $25^{\circ} \mathrm{C}$ is 7.8 in days, in which the egg period occupies ca. $45 \%$. The developmental zero and effective heat units from egg to adult are $8.8^{\circ} \mathrm{C}$ and 123.7 day-degrees, respectively. The number of annual generations in Okayama Prefecture is estimated to be $18.8^{16}$.

\section{Chemical control}

Most acaricides except hexythiazox and fenbutatin oxide have high activities for control of $A$. fockeui adults, showing nearly $100 \%$ mortalities. More than $80 \%$ mortalities are found in insecticides such as ethiofencarb, alanycarb, fenpropathrin, acrinathrin, bifenthrin, chlorfenapyr, sodium oleat, calcium polysulfide and spray oil, and also in some fungicides such as wettable sulfur and procymidone $^{16}$.

To clarify the optimum timing for control, an acaricide pyridaben, which is a highly effective chemical for A. fockeui with only minor effects on phytoseiid mites, was sprayed on peach trees at different times, comparing the leaf injury levels at fruit harvest. As a result, the minimum leaf injury level was detected when sprayed in early July, which would be the optimum timing of acaricide applications for A. fockeui. However, a single acari-

Table 7. Developmental parameters of Aculus fockeui under different temperatures

\begin{tabular}{|c|c|c|c|c|c|}
\hline \multirow{2}{*}{$\begin{array}{l}\text { Temperature } \\
\left({ }^{\circ} \mathrm{C}\right)\end{array}$} & \multirow{2}{*}{$\begin{array}{l}\text { Egg hatchability } \\
\qquad(\%)\end{array}$} & \multirow{2}{*}{$\begin{array}{c}\text { Survival rate of } \\
\text { immature stages } \\
(\%)\end{array}$} & \multicolumn{3}{|c|}{ Duration in days } \\
\hline & & & Egg & Immature stage & Egg to adult \\
\hline \multirow[t]{2}{*}{15} & 43.9 & 35.9 & $11.45 \pm 0.32^{\mathrm{b})}$ & $7.52 \pm 0.33$ & $18.87 \pm 0.30$ \\
\hline & $(66)^{\mathrm{a})}$ & (64) & (29) & (23) & (23) \\
\hline \multirow[t]{2}{*}{20} & 75.0 & 69.1 & $6.00 \pm 0.19$ & $5.32 \pm 0.14$ & $11.37 \pm 0.18$ \\
\hline & $(60)$ & $(55)$ & (45) & (38) & (38) \\
\hline \multirow[t]{2}{*}{25} & 90.9 & 61.2 & $3.58 \pm 0.08$ & $4.03 \pm 0.16$ & $7.77 \pm 0.13$ \\
\hline & (55) & (49) & $(50)$ & (30) & (30) \\
\hline \multirow[t]{2}{*}{30} & 86.8 & 75.8 & $3.42 \pm 0.07$ & $2.36 \pm 0.09$ & $5.74 \pm 0.11$ \\
\hline & (68) & (66) & (59) & (50) & (50) \\
\hline
\end{tabular}

a): number of individuals tested.

b): mean \pm standard error. 
cide spraying in early July could not suppress the leaf injuries sufficiently, and so an additional spraying in late July or early August would be needed. Although postharvest sprayings in early- or mid-ripening varieties are often omitted, it is also important to spray at this time to prevent early post-harvest defoliation by $A$. fockeui. Further, winter sprayings of spray oil in early February and calcium polysulfide in early March are effective to suppress the overwintering populations of $A$. fockeui in buds ${ }^{16}$.

\section{Biological control}

Applications of synthetic pyrethroids, which have wide insecticidal spectrums against peach pests such as fruit borers, aphids and spider mites, are considered to be one of the critical factors related to outbreaks of $A$. fockeui in Japan, because the injuries have become conspicuous with the popularization of synthetic pyrethroids. To clarify the factors affecting such mite outbreaks, the effect of applications of a synthetic pyrethroid fluvalinate on changes in the population densities of A. fockeui and its possible natural enemies was examined. Population densities of two species of phytoseiid mites, Amblyseius sojaensis Ehara and A. eharai, were high from June to August in a peach orchard with no applications of fluvalinate, whereas phytoseiid mites did not occur until early September in a peach orchard where fluvalinate had been
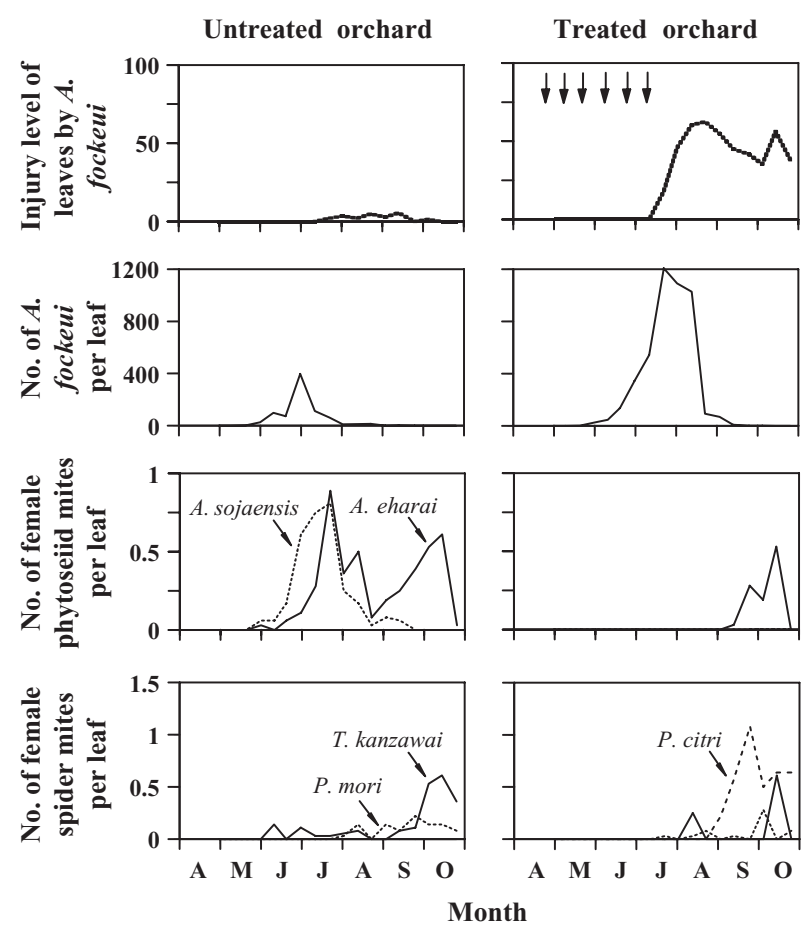

Fig. 9. Effect of fluvalinate

applications on the seasonal population trend of Aculus fockeui, phytoseiid mites and spider mites in peach orchards sprayed 6 times from late April to early July (Fig. 9). This resulted in the peak density of $A$. fockeui reaching ca. 3 times the size of that in the untreated orchard. As a result, the injury level of leaves in the untreated orchard was exceedingly low until late October, whereas those in the treated orchard increased rapidly from late July, reaching a high level in mid-August. Thus, a marked resurgence of $A$. fockeui could occur because of the exclusion of phytoseiid mites when synthetic pyrethroids, which have no effect on $A$. fockeui and are harmful to the predators, are sprayed ${ }^{15}$. In other words, it is expected that the density of $A$. fockeui could be suppressed at low levels by the predatory activities when pesticides which have minor effects on phytoseiid mites are selected. For A. eharai, many insecticides are harmful, but diazinon, diflubenzuron, teflubenzuron, imidacloprid, acetamiprid and pyridaben have minor effects, and most fungicides are not harmful ${ }^{16}$.

Functional responses of the two phytoseiid mites to the density of $A$. fockeui showed saturation curves, in which the maximum number of $A$. fockeui consumed per female per day was estimated to be ca. 300 and 400 for $A$. sojaensis and A. eharai, respectively (Fig. 10). Thus, the

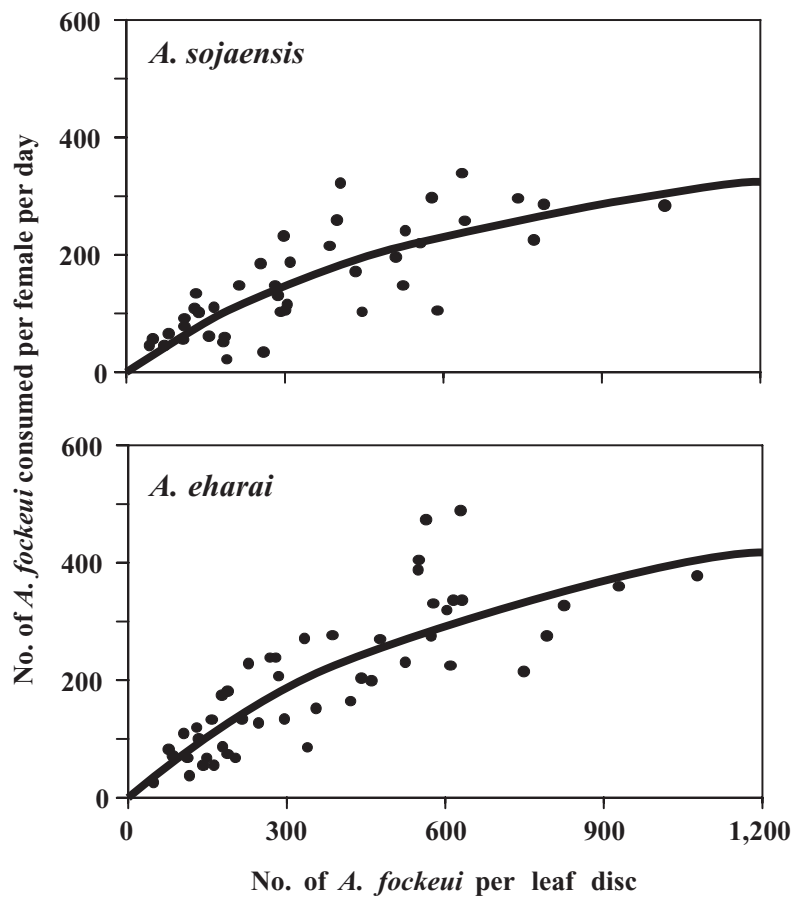

Fig. 10. Functional responses of two species of female phytoseiid mites, Amblyseius sojaensis and A. eharai, to the density of nymphs and adults of Aculus fockeui

Curves were fitted to Holling's disc-equation $(A$. sojaensis: $\mathrm{y}=0.673 \mathrm{x} /\left(1+1.245 \times 10^{-3} \mathrm{x}\right), n=42$, $r=0.794, \mathrm{p}<0.001 ;$ A. eharai: $\mathrm{y}=0.883 \mathrm{x} /(1+$ $\left.\left.1.136 \times 10^{-3} \mathrm{x}\right), n=48, r=0.832, p<0.001\right)$. 
two phytoseiid mites had great abilities to prey on $A$. fockeui, although the ability of $A$. sojaensis was somewhat inferior to that of $A$. eharai ${ }^{14}$. These also support the field results mentioned above that the two phytoseiid mites could play important roles in suppressing the density of $A$. fockeui.

\section{Concluding remarks}

Phytoseiid mites have a great effect on the population density of $A$. fockeui, and this results in low injury levels of leaves in the peach orchard with no pyrethroid applications (Fig. 9). On the contrary, a marked resurgence occurs in the peach orchard with pyrethroid applications, which have no effect on A. fockeui and are harmful to phytoseiid mites. In order to manage the population density of $A$. fockeui at low levels, it is necessary to establish a pesticide control system which has minor effects on phytoseiid mites, but is effective against $A$. fockeui and other peach pests such as fruit borers, aphids and spider mites.

It might be possible that species or densities of natural enemies of $A$. fockeui differ according to regions or peach orchards. Therefore, such investigations on natural enemies in various regions or peach orchards should also be carried out to clarify other environmental conditions such as ground cover under trees which enhance the colonization of phytoseiid mites.

(Kondo)

\section{Pink citrus rust mite, Aculops pelekassi}

The pink citrus rust mite, Aculops pelekassi is distributed around the Mediterranean Sea, and in Thailand, Japan, Taiwan, Florida and Brazil ${ }^{12}$. In Japan, damage caused by this mite was first recorded in the early 20th century as 'elephantiasis' of citrus ${ }^{36}$. Basic studies on the biology and management of $A$. pelekassi were conducted by Seki $(1975)^{26}$. Recently this mite is sometimes present in heavy infestations, because dithiocarbamate resistant populations were established in the early 1990's.

\section{Seasonal cycle}

Adults of $A$. pelekassi overwinter within the scales of citrus tree buds. They begin to lay eggs on the sprouting buds in mid-April, and the populations begin to increase thereafter. The population density of the mite on leaves reaches a peak between late June and late July. Although the density decreases markedly from early September, a few mites are still found on the leaves in the middle of November or even early in December. After late June, A. pelekassi begins to disperse from the leaves and shows peak densities on fruit from late July to
August. Population densities on fruits decrease after September and adults move to their overwintering site after October. When autumn temperatures are higher than usual, the population density remains high through early November ${ }^{19,26}$.

The developmental zero and effective heat units from egg to adult are $10.6^{\circ} \mathrm{C}$ and 119 degree-days, respectively ${ }^{26}$. It was once thought that $A$. pelekassi populations lacked males, because Huang $(1971)^{4}$ recorded only adult females in specimens collected on citrus in Japan. However, observation of spermatophores on citrus leaves ${ }^{32}$ and of the genital organs of specimens ${ }^{7}$ indicated the presence of male mites. The sex ratio of the adults is biased toward females and changes seasonally: the proportions of females were $84 \%$ in October and $100 \%$ in December.

\section{Damage}

When $A$. pelekassi adults feed on Citrus sinensis Osbecr. fruits, they make about 20 feeding punctures, each ca. $1 \mu \mathrm{m}$ in diameter per epidermal cell $(10 \mu \mathrm{m} \times 7$ $\mu \mathrm{m})$. The depth of penetration is ca. $20 \mu \mathrm{m}$ and reaches to the 2nd and 3rd layer of the fruit epidermis ${ }^{32}$.

Callus formation on the peel surface of Citrus unshiu Marc. occurs at early infestation in August, when cells in the epidermis and hypodermis of the peel are actively dividing. Late infestations from September to October cause bronzing injury. Mite injury during the middle stage of fruit growth results in both types of symptoms near the oil glands ${ }^{10}$. The diameter, volume and weight of damaged fruits are less than those of undamaged fruits. The sugar content of juice from damaged fruit is higher than that from undamaged fruits, suggesting concentration of soluble solids via water loss caused by mite infestation ${ }^{34}$.

\section{Chemical control}

Most acaricides except for hexythiazox, etoxazole and acequinocyl are effective against $A$. pelekassi. Insecticides such as chlorfenapyr and diflubenzuron are also effective $^{19,23}$. Because dithiocarbamate fungicides sprayed more than twice a year against melanose simulta-

Table 8. Development of Amblyseius eharai, A. longispinosus and Agistemus terminalis from egg to adult supplied with Aculops pelekassi as food at $25^{\circ} \mathrm{C}$ and $16 \mathrm{~L}: 8 \mathrm{D}$

\begin{tabular}{lcc}
\hline Predatory mites & No. of eggs & $\begin{array}{c}\% \text { of development } \\
\text { from egg to adult }\end{array}$ \\
\hline Amblyseius eharai & 26 & 0 \\
A. longispinosus & 20 & 0 \\
Agistemus terminalis & 30 & 62.5 \\
\hline
\end{tabular}


Table 9. Development of Agistemus terminalis fed on Aculus pelekassi at $25^{\circ} \mathrm{C}$ and $16 \mathrm{~L}: 8 \mathrm{D}$

\begin{tabular}{lccc}
\hline \hline Stage & No. of individuals tested & $\begin{array}{c}\text { No. of individuals } \\
\text { developed to next } \\
\text { stage (\%) }\end{array}$ & $\begin{array}{c}\text { Developmental time in } \\
\text { days }\end{array}$ \\
\hline Egg & 25 & $21(84)$ & $4.9 \pm 0.53$ \\
Larva & 21 & $15(71)$ & $2.4 \pm 0.49$ \\
Nymph & 15 & $9(60)$ & $4.2 \pm 0.42$ \\
\hline
\end{tabular}

Table 10. Oviposition of Agistemus teminalis supplied with Aculops pelekassi at $25^{\circ} \mathrm{C}$ and 16L:8D

\begin{tabular}{lcccccc}
\hline \hline & \multicolumn{7}{c}{ Days after start } \\
\cline { 2 - 7 } & 1 & 2 & 3 & 4 & 5 & 6 \\
\hline No. of surviving females ${ }^{\text {a) }}$ & 16 & 12 & 10 & 8 & 5 & 0 \\
Mean no. of eggs laid /female & 1.8 & 2.6 & 2.8 & 1.8 & 2.2 & 1.6 \\
\hline
\end{tabular}

a): Test was started with 20 adult females collected from Podocarpus macrophyllus in October 2000.

neously control $A$. pelekassi, it was unnecessary to pay special attention to the mite population when these fungicides were used. After establishment of a dithiocarbamate-resistant strain of $A$. pelekassi was confirmed in the early $1990 \mathrm{~s}$, the mite has sometimes had outbreaks and caused severe damage to citrus fruits. The $\mathrm{LC}_{50}$ value of mancozeb to a resistant strain is $3,479 \mathrm{ppm}$, which is about 4.6 times higher than the practical recommended concentration $^{24}$. To maintain $A$. pelekassi population at low densities, it is recommended to use chlorfenapyr for Scirtothrips dorsalis Hood, diflubenzuron for Phyllocnistis citrella Stainson, and fluazinam for melanose, because these pesticides are also effective against the mite.

\section{Biological control}

No literature is available on natural enemies of $A$. pelekassi on citrus in Japan. We observed that infestations of $A$. pelekassi are rare in a citrus grove in Nagasaki Prefecture where no pesticides have been sprayed. When 3 predatory mites, Agistemus terminalis (Quayle), Amblyseius eharai and $A$. longispinosus Muma collected in the grove were provided with $A$. pelekassi as food, A. terminalis could develop to adulthood (Tables $8 \&$ 9) and produced eggs (Table 10). A. terminalis is common in citrus trees and their windbreaks, especially on Podocarpus macrophyllus D. Don ${ }^{5}$ A. terminalis mite inhabiting windbreaks may be a factor of some significance in reducing infestations of $A$. pelekassi. Further research is needed on the relationships between mite infestations and predatory mite populations on trees around citrus groves.

\section{Concluding remarks}

Because citrus fruits are produced mainly for the fresh market in Japan, A. pelekassi infestation is an important problem to citrus production demanding high cosmetic quality. After the establishment of dithiocarbamate-resistant $A$. pelekassi populations, citrus farmers sprayed acaricides in June and September against $A$. pelekassi. For effective management of this eriophyid mite, we need to develop simple and accurate monitoring methods and to elucidate the roles of their natural enemies as control agents.

(Ashihara)

\section{References}

1. Hiehata, K. (1995) Occurrence and injury of persimmon bud mite, Aceria diospyri Keifer, in persimmon fruits in Yamaguchi Prefecture. Bull. Yamaguchi Exp. Stn., 46, 114-119 [In Japanese with English summary].

2. Hiehata, K. \& Izumi, K. (2001) Occurrence and control of the persimmon bud mite. Shokubutsu-Boeki (Plant Prot.), 55, 347-351 [In Japanese].

3. Hiehata, K. \& Izumi, K. (2002) Biology of persimmon bud mite (Aceria diospyri Keifer) and its control by pesticides. Bull. Yamaguchi Exp. Stn., 53, 65-72 [In Japanese with English summary].

4. Huang, T. (1971) Records of ten eriophyid mites associated with plants in Japan. J. Fac. Sci. Hokkaido Univ. Ser. IV, Zool., 18, 271-273.

5. Inoue, K., Ashihara, W. \& Osakabe, M. (1991) Predator fauna on windbreaks around citrus groves. Jpn. J. Appl. Entomol. Zool., 35, 49-56 [In Japanese with English summary].

6. Kadono, F. (1985) Three species of eriophyid mites injurious to fruit trees in Japan (Acarina: Eriophyidae). Appl. Entomol. Zool., 20, 458-464.

7. Kadono, F. \& Ashihara, W. (1993) Pink citrus rust mite. In Plant mites of Japan in color, ed. Ehara, S., Zenkoku 
Nouson Kyouiku Kyoukai, Tokyo, Japan, 150-151 [In Japanese].

8. Kadono, F. (1995) Taxonomic studies on eriophyid mite on trees in Japan and ecological studies on the Japanese pear rust mite, Eriophyes chibaensis Kadono on pear trees (Acari: Eriophyidea). Spec. Bull. Chiba Agric. Exp. Stn., 30, 1-87 [In Japanese with English summary].

9. Kadono, F. (1996) Eriophyidae. In Principles of plant acarology, eds. Ehara, S. \& Shinkaji, N., Zenkoku Nouson Kyouiku Kyoukai, Tokyo, Japan, 204-248 [In Japanese].

10. Kato, T. (1977) Qualitative change of Satsuma mandarin fruits infested with the Japanese citrus mite, Aculops pelekassi (Keifer). Bull. Yamaguchi Expt. Stn., 28, 129137 [In Japanese with English summary].

11. Keifer, H. (1944) Eriophyid studies XIV. Bull. Calif. Dept. Agric., 33, 18-38.

12. Keifer, H. (1975) The Eriophyoidea Nalepa. In Mites injurious to economic plants, eds. Jeppson, L.R., Keifer, H.H. \& Baker, E.W., University of California Press, Berkeley, California, 327-396.

13. Kondo, A. \& Hiramatsu, T. (1999a) Analysis of peach tree damage caused by peach silver mite, Aculus fockeui (Nalepa et Trouessart) (Acari: Eriophyidae). Jpn. J. Appl. Entomol. Zool., 43, 189-193 [In Japanese with English summary].

14. Kondo, A. \& Hiramatsu, T. (1999b) Predatory ability of two species of phytoseiid mites (Acari: Phytoseiidae) on the peach silver mite, Aculus fockeui (Nalepa et Trouessart) (Acari: Eriophyidae). Appl. Entomol. Zool., 34, 485-487.

15. Kondo, A. \& Hiramatsu, T. (1999c) Resurgence of the peach silver mite, Aculus fockeui (Nalepa et Trouessart) (Acari: Eriophyidae) induced by a synthetic pyrethroid fluvalinate. Appl. Entomol. Zool., 34, 531-535.

16. Kondo, A. (2001) Biology and control of the peach silver mite, Aculus fockeui (Nalepa et Trouessart). ShokubutsuBoeki (Plant Prot.), 55, 352-356 [In Japanese].

17. Kunugi, Y., Terai, Y. \& Kato, S. (1993) Seasonal occurrence of peach silver mite, Aculus fockeui (Nalepa et Trouessart), on peach leaves and their effects on fruit development. Proc. Kanto-Tosan Plant Prot. Soc., 40, 269-271 [In Japanese with English summary].

18. Manson, D. C. M. (1989) New species and records of eriophyid mite from New Zealand. NZ. J. Zool., 16, 3750 .

19. Nakamura, Y. (2002) Occurrence and control of the pink citrus mite and citrus red mite in Nagasaki Prefecture. Kongetsu no Nogyo (Monthly Agric. Mag.), 46(8), 31-35 [In Japanese].

20. Nakasone, W. \& Kusakari, S. (1991) Occurrence and control of fig mosaic disease caused by mites. Proc. Kansai Plant Prot., 33, 116 [In Japanese].

21. Nemoto, H. et al. (1980) Studies on eriophyid mites I. Two Eriophyid mites injurious to fig and chrysanthemum in Japan. Jpn. J. Appl. Entomol. Zool., 24, 49-53 [In Japanese with English summary].

22. Nemoto, H. (1982) Some eriophyid species from trees in
Japan. Proc. Jpn. Acarol. Soc., 9, 1 [In Japanese].

23. Ogihara, H. (2002) Control of mites infesting citrus. Kongetsu no Nogyo (Monthly Agric. Mag.), 46(8), 26-30 [In Japanese].

24. Qu, S. C. et al. (1997) Occurrence of dithiocarbamate resistance strain and its susceptibilities to several chemicals in the pink citrus rust mite, A. pelekassi (Keifer), in Saga Prefecture. Proc. Assoc. Plant Prot. Kyushu, 43, 125-129 [In Japanese with English summary].

25. Rossetto, C. J. et al. (1971) Queda dos frutos do caquizeiro, associada à infestação de Aceria diospyri $\mathrm{K}$. (Acarina, Eriophydae). Bragantia, 30, 1-9.

26. Seki, M. (1975) Ecological studies of the pink citrus rust mite, Aculops pelekassi (Keifer), with special reference to the life cycle, forecasting of occurrence and chemical control of A. pelekassi. Spec. Bull. Saga Pref. Fruit Tree Exp. Stn., 2, 1-66 [In Japanese with English summary].

27. Shibao, M., Tanaka, H. \& Kimura, Y. (1994) Seasonal fluctuation of the fig bud mite, Eriophyes ficus Cotte, and effects of acaricides on the mite. Proc. Kansai Plant. Prot., 36, 47-48 [In Japanese].

28. Shibao, M. Tanaka, H. \& Kimura, Y. (1995) Effects of insecticides, fungicides and acaricides on the fig bud mite, Eriophyes ficus Cotte. Proc. Kansai Plant Prot., 37, 21-22 [In Japanese].

29. Shibao, M. \& Tanaka, H. (1997) Overwintering sites and stages of the fig bud mite, Eriophyes ficus Cotte. Proc. Kansai Plant Prot., 39, 1-3 [In Japanese with English summary].

30. Shibao, M. \& Tanaka, H. (1998) Effects of acaricides and fungicides application and optimum timing for control of the ficus mottle mite, Aceria ficus Cotte. J. Acarol. Soc. Jpn., 7, 107-113 [In Japanese with English summary].

31. Shibao, M. (2001) Occurrence and control of the ficus mottle mite, Aculus ficus Cotte. Shokubutsu-Boeki (Plant Prot.), 55, 357-360 [In Japanese].

32. Takagi, K. (1981) The injuries on the citrus fruit caused by green leafhoppers, Emposca spp., tea yellow thrips, Scirtothrips dorsalis Hood, citrus red mite, Panonychus citri (McGregor) and citrus rust mite, A. pelekassi. Bull. Fruit Tree Res. Stn. D3, 101-112 [In Japanese with English summary].

33. Tanaka, H. (1992) Biology and control of pest on common fig. Kongetsu no Nogyo (Monthly Agric. Mag.), 36(1), 96-100 [In Japanese].

34. Tono, T., Fujita, S. \& Yamaguchi, S. (1978) Effect of infestation by citrus rust mite, Aculus pelekassi Keifer, on the development of Satsuma mandarin fruit and availability for juice processing from damaged fruit. Bull. Fac. Agric. Yamaguchi Univ., 44, 57-66 [In Japanese with English summary].

35. Tsuchiya, T. (1989) Occurrence and damage of peach silver mite, Aculus fockeui (Nalepa et Trouessart) on peaches in Yamanashi Prefecture. Shokubutsu-Boeki (Plant Prot.), 43, 538-539 [In Japanese].

36. Yano, N. (1909) Elephantiasis on citrus. Kaju (Fruit), 78, 10-21 [In Japanese]. 